\title{
Response of Flowering Parameters of Alstoemeria to Organic and Inorganic Fertilizers under Protected Conditions
}

\author{
S.A. Samoon ${ }^{1}$, Neelofar ${ }^{1}$, Malik Asif ${ }^{2 *}$ and Mubashir A. Wani ${ }^{1}$ \\ ${ }^{1}$ Division of Floriculture and Landscape Architecture, Sher-e-Kashmir University of \\ Agricultural Sciences and Technology of Kashmir Shalimar Srinagar, J\&K, India \\ ${ }^{2}$ Division of Basic Science \& Humanities, FOA, Wadura Campus, Sher-e-Kashmir University \\ of Agricultural Sciences and Technology of Kashmir Shalimar Srinagar, J\&K, India \\ *Corresponding author
}

\section{Key words \\ Alstroemeria, FYM, Phosphorus, Vermicompost \\ Article Info \\ Accepted: \\ 10 August 2018 \\ Available Online: \\ 10 September 2018}

\section{A B S T R A C T}

An experiment entitled response of alstomeria to organic and inorganic fertilizers under protected conditions was conducted with three levels of nitrogen viz 150, 200 and $250 \mathrm{ppm} / 15$ days of interval, two levels of phosphorus 100 and $150 \mathrm{~kg} / \mathrm{ha}$ and three levels of organic manure Vermicompost $2.5 \mathrm{t} / \mathrm{ha}$, FYM 5t/ha and sheep manure 5 t/ha respectively. The results revealed that various levels of nitrogen, Phosphorus and organic manure had a significant influence on various flowering parameters. Nitrogen at $250 \mathrm{ppm} / 15$ days interval recorded minimum days to appearance of cymes (176.68 days) minimum days taken from appearance of cymes to flower harvesting stage (7.60 days) maximum duration of flowering flush (78.29) maximum number of flowering shoots/plant (91.99) and maximum total number of flowers per plant at 45 days for interval of 37-35 similarly the influence of phosphorus on various floral parameters was found significant with phosphorus level of $150 \mathrm{~kg} / \mathrm{ha}$ recording minimum days to appearance of cymes (178.44) minimum days taken from appearance of cymes to flower harvesting stage (7.70), maximum duration of flowering flush (72.31 days) maximum number of flowering shoots/plant (84.71) and maximum total number of flowers/plant at 45 days of interval (35.79). Similarly among the organic manure Vermicompost recorded minimum days taken to appearance of cymes (179.26), minimum days taken from appearance of cymes to flower harvesting stage (7.68) maximum duration of flowering flush (74.86 days) and maximum total number of flowers per plant at 45 days of individual (40.49). The interaction between N3P1 recording minimum days (7.21) taken from appearance of cymes to flower harvesting stage, minimum duration of flowering flush (79.25 days) and maximum number of flowering shoots/plant (94.70). The interaction between N3O3 recorded maximum number of shoots per plant (96.49). The interaction between phosphorus and organic manure had a significant influence on recording minimum days taken from appearance of cymes to flower harvesting stage (7.22) at $\mathrm{P} 2 \mathrm{O} 3$ and maximum number of flowering shoots /plant (89.88) at treatment combination of P1O3. The interaction effect of $(\mathrm{NxPxO})$ were however non-significant. 


\section{Introduction}

Alstroemeria is an important cut flower and occupies global position within top ten cut flowers. It is also called Peruvian Lily. It belongs to family Alstroemeracea and is native to South America. It has become a competitive greenhouse cut flower crop. In the world it occupies about 400 ha. under its cultivation. It is a perennial and rhizomatous plant. Being new crop to Indian atmosphere many private companies, farmers and farmers cooperatives are importing its planting material from abroad. It is gaining popularity in Indian flower market due to its long stem flowers, prolonged vase life and various color of shades of petals. In India it is of a recent introduction. The crop has a perennial potential as a cut flower because it needs relatively low temperatures for growth and development (Heins and Wilkins, 1977).

The plants bear attractive flowers with wide range of colors and excellent keep-ability. The flowers are beautiful and have very long vase life. The soil should be kept moist as Alstroemeria produces the most blooms with moist soil and may become dormant if the soil becomes too dry. Do not allow the soil to remain soggy, as excessively wet soil causes rot and fungal diseases. Feed the plants in spring, using a general purpose time release fertilizer. Spread 2-3 inches of mulch such as compost or shredded bark around the plant in spring Mulch enriches the soil, keep roots cool and extends blooming period. Replace the mulch as it decomposes or blows away.

Being new crop information on nutritional requirements of Alstroemeria is scarce in particular with respect to quality characteristics under poly house conditions. Hence the experiment was carried out keeping in view to standardization of nutritional requirements for flowering parameters of Alstroemeria under poly houses conditions.

\section{Materials and Methods}

The present investigation entitled response of Alstroemeria to organic and inorganic fertilizers under protected conditions was carried out at the experimental field of Division of Floriculture and Landscape Architecture Sher-e-Kashmir University of Agricultural Science and Technology of Kashmir Shalimar campus Srinagar form 2011-2013, at an altitude of 1558 meters above mean sea level.

The climate in general is temperate cum Mediterranean. Average winter temperature range from 0 to $-3{ }^{\circ} \mathrm{C}$ and average summer temperature ranges from $29-34^{\circ} \mathrm{C}$. For better plant growth and quality flower production the optimum day and night temperature during growth period should be maintained between $18-22{ }^{\circ} \mathrm{C}$ and $12-16{ }^{\circ} \mathrm{C}$ respectively.

The soil of the experimental plot was analyzed by the division of soil science SKUAST-K and found to be silty clayloam in texture having good water holding capacity. The land was thoroughly prepared before planting of rhizomes. The soil was dug upto depth of 30 $\mathrm{cm}$. The clods were broken-up till it reached to fine tilth. The beds were divided into uniform size and were in raised form to prevent water stagnation.

Inorganic fertilizers like nitrogen application were done after an interval of 15 days through fertigation. Phosphorus was applied as a basal dose before planting of rhizomes through source single super phosphate at concentrations of 100 and $150 \mathrm{~kg} / \mathrm{ha}$. Organic manure like Vermicompost (2.5 t/ha.) farmyard manure (5t/ha) and sheep manure (5t/ha) was added to the well prepared beds as per technical programme and mixed well before planting of rhizomes. Single rhizomes of uniform and healthy nature were planted at a spacing of 30 x $45 \mathrm{~cm} @$ six rhizomes/bed. 
Cultural operations started after complete field preparations. Watering was done immediately after planting and thereafter twice or thrice a week depending upon moisture content of the soil. Shading was provided using 50\% shade nets during periods of high light intensity and temperature. Weeding and hoeing was done regularly after every fortnight.

\section{Results and Discussion}

\section{Effects of nitrogen}

Effect of Nitrogen influenced flowering parameters likes days taken to appearance of cymes, duration of flowering flush maximum number of flowering shoots/plant, total number of flowers/plants at 45 days after the appearance of first cymes etc. Nitrogen at $250 \mathrm{ppm} / 15$ days interval recorded minimum days to appearance of cymes (176.68), maximum duration of 78.29 days of flowering flush, maximum number of 91.99 flowering shoots/plant at maximum of 45 days after the appearance of first cyme (37.03).

This lends support from findings of smith et al., (1998) who reported that Alstroemeria plants fertilized with $\mathrm{N}$ at $400 \mathrm{mg} / \mathrm{l}$ every $7-10$ days produced more flowering of higher quality with earlier on set of flowering. Similar results were obtained by Herman (1986) with $\mathrm{N}$ at $30-40 \mathrm{~g} / \mathrm{m} 2$ in Alstroemeria producing maximum flower yield/plant over a period of two years, thus confirming the results of Bik and Vanden Berg (1982) Blomme and Dambre (1982) and Lisiecka and Szczepanik (1983).

\section{Effect of phosphorus}

It is evident from the analyzed data present in table 1 that phosphorus at various levels played a significant role in improving the flowering parameters in Alstroemeria. In the present study phosphorus at $150 \mathrm{~kg} / \mathrm{ha}$ was significantly superior over other treatments in reducing number of days for appearance of cymes (178.44) extending flowering duration (72.31 days) increased number of flowering stems/plant at 45 days interval (35.79).

Phosphorus is one of the major players in the process of photosynthesis, nutrient, transport, energy transport and affects the plant structure at cellular level, that is why plants with adequate level of phosphorus will grow more vigorously. The above parameters lends support from the study by Lisiecka and Szczepaniak (1992) who obtained highest flower yield in Alstroemeria at $150-300 \mathrm{mg} / \mathrm{l}$. Baboo et al., (2005) reported earlier flowering in marigold with maximum yield when plants were treated with highest dose of phosphorus.

Similar results were obtained by Madson (1995) while working with potted Alstroemeria hybrid FL-101, and found that increasing phosphorus fertilization upto 74 $\mathrm{mg} / \mathrm{l}$ applied at every irrigation during the production phase increased subsequent yield of flowers and total number of florets/stem.

Also the results are in conformity with the results of khan and Iftikhar (2004) who worked on various levels of phosphorus on gladiolus and found that spike emergence, opening of first and last floret and maximum number of florets/spike was found at $5 \mathrm{~g} / \mathrm{plot}$

\section{Effect of organic manure}

Organic manures had a significant influence on flowering parameters of Alstroemeria. As is evident from table 1 application of Vermicompost at $2.5 \mathrm{t} /$ ha proved significantly superior in improving flowering parameters e.g., reduction in number of days to appearance of cymes (179.26) maximum duration of flowering flush (74.86 days) and maximum number of flowers/plants at 45 days after the appearance of first cyme (40.49). 
Table.1 Effects of nitrogen, phosphorus and organic manure on flowering parameters of Alstroemeria

\begin{tabular}{|l|}
\hline Treatment \\
\\
\hline Nitrogen $(\mathrm{ppm})$ \\
N1-(150 ppm) \\
N2-(200 ppm) \\
N3-(250 ppm) \\
\hline CD(P=0.05) \\
\hline Phosphorus Kg/ha \\
P1-(100 kg/ha) \\
P2-(150 kg/ha) \\
\hline CD (P=0.05) \\
\hline Organic Manure (t/ha) \\
01-(2.5 t/ha) \\
02-(5 t/ha) \\
03-(5 t/ha) \\
\hline CD (P=0.05) \\
\hline
\end{tabular}

\begin{tabular}{|c|c|c|c|c|}
\hline $\begin{array}{ll}\text { Days } & \text { to } \\
\text { appearance of } \\
\text { Cymes }\end{array}$ & $\begin{array}{l}\text { Days taken from } \\
\text { appearance of } \\
\text { cymes to flower } \\
\text { harvesting stage }\end{array}$ & 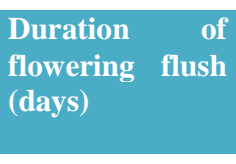 & $\begin{array}{l}\text { Total No. of } \\
\text { Flowering } \\
\text { shoots/plant }\end{array}$ & $\begin{array}{l}\text { Total No of flowers/plant } \\
\text { at } 45 \text { days of interval after } \\
\text { appearance of } 1^{\text {st }} \text { cyme }\end{array}$ \\
\hline $\begin{array}{l}188.72 \\
180.85 \\
176.68\end{array}$ & $\begin{array}{l}7.95 \\
7.68 \\
7.60\end{array}$ & $\begin{array}{l}60.82 \\
71.31 \\
78.29\end{array}$ & $\begin{array}{l}76.90 \\
80.81 \\
91.99\end{array}$ & $\begin{array}{l}30.16 \\
29.60 \\
37.03\end{array}$ \\
\hline 3.33 & NS & 3.80 & 6.23 & 4.41 \\
\hline $\begin{array}{l}185.73 \\
178.44\end{array}$ & $\begin{array}{l}7.79 \\
7.70\end{array}$ & $\begin{array}{l}67.97 \\
72.31\end{array}$ & $\begin{array}{l}81.76 \\
84.71\end{array}$ & $\begin{array}{l}28.73 \\
35.79\end{array}$ \\
\hline 2.72 & NS & 3.10 & NS & 3.60 \\
\hline $\begin{array}{l}179.26 \\
181.96 \\
185.03\end{array}$ & $\begin{array}{l}7.68 \\
7.75 \\
7.81\end{array}$ & $\begin{array}{l}74.86 \\
67.90 \\
67.66\end{array}$ & $\begin{array}{l}82.20 \\
81.83 \\
85.68\end{array}$ & $\begin{array}{l}40.49 \\
24.53 \\
31.77\end{array}$ \\
\hline 3.33 & NS & 3.80 & NS & 4.41 \\
\hline
\end{tabular}

Table.2 Effects of different organic and inorganic fertilizer interactions on flowering parameters of Alstroemeria

\begin{tabular}{|l|}
\hline Treatment \\
\\
\hline Nitrogen x Phosphorus \\
N1 P1 \\
N1 P2 \\
N2 P1 \\
N2 P2 \\
N3 P1 \\
N3 P2 \\
\hline CD (P=0.05) \\
\hline Nitrogen $x$ Organic Manure \\
N1 O1 \\
N1 O2 \\
N1 O3 \\
N2 O1 \\
N2 O2 \\
\hline N2 O3 \\
N3 O1 \\
N3 O2 \\
N3 O3 \\
\hline CD (P=0.05) \\
\hline Phosphorus x Organic Manure \\
P1 O1 \\
P1 O2 \\
P1 O3 \\
P2 O1 \\
P2 O2 \\
P2 O3 \\
\hline CD (P=0.05) \\
\hline \\
\hline
\end{tabular}

\begin{tabular}{|c|c|c|c|c|}
\hline $\begin{array}{l}\text { Days to } \\
\text { appearance of } \\
\text { Cyme }\end{array}$ & $\begin{array}{l}\text { Days taken from } \\
\text { appearance of } \\
\text { cyme to flower } \\
\text { harvesting stage }\end{array}$ & 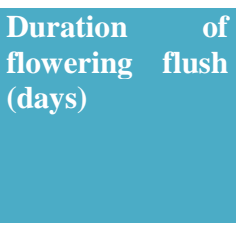 & $\begin{array}{l}\text { Total No. of } \\
\text { Flowering } \\
\text { shoots/plant }\end{array}$ & $\begin{array}{l}\text { Total No. of } \\
\text { flowers/plant at } \\
45 \text { days of } \\
\text { interval after } \\
\text { appearance of } 1^{\text {st }} \\
\text { cyme }\end{array}$ \\
\hline 193.26 & 8.62 & 57.73 & 81.58 & 24.36 \\
\hline 184.18 & 7.29 & 63.92 & 72.22 & 35.95 \\
\hline 184.70 & 7.55 & 66.92 & 68.99 & 25.88 \\
\hline 177.00 & 7.81 & 75.69 & 92.62 & 33.32 \\
\hline 179.22 & 7.21 & 79.25 & 94.70 & 35.96 \\
\hline 174.13 & 7.99 & 77.33 & 89.29 & 38.10 \\
\hline NS & 1.21 & 5.37 & 8.81 & NS \\
\hline 186.89 & 7.94 & 63.55 & 81.38 & 38.77 \\
\hline 188.66 & 7.77 & 59.16 & 71.10 & 22.99 \\
\hline 190.61 & 8.16 & 59.77 & 78.21 & 28.71 \\
\hline 175.38 & 7.77 & 75.21 & 72.38 & 38.66 \\
\hline 182.72 & 7.05 & 69.10 & 87.71 & 21.55 \\
\hline 184.44 & 8.22 & 69.60 & 82.32 & 28.60 \\
\hline 175.50 & 7.33 & 85.83 & 92.83 & 44.05 \\
\hline 174.50 & 8.44 & 75.44 & 86.66 & 29.05 \\
\hline 180.04 & 7.05 & 73.60 & 96.49 & 37.99 \\
\hline NS & NS & NS & 10.79 & NS \\
\hline 182.59 & 7.73 & 74.44 & 76.58 & 35.44 \\
\hline 185.81 & 7.25 & 64.18 & 78.81 & 22.33 \\
\hline 188.77 & 8.40 & 65.29 & 89.88 & 28.44 \\
\hline 175.92 & 7.62 & 75.29 & 87.81 & 45.55 \\
\hline 178.11 & 8.25 & 71.62 & 84.84 & 26.73 \\
\hline 181.28 & 7.22 & 70.03 & 81.47 & 35.10 \\
\hline NS & 1.08 & NS & 8.81 & NS \\
\hline
\end{tabular}


Table.3 Effects of (Nitrogen x Phosphorus x Organic Manure) interaction on flowering parameters of Alstroemeria

\begin{tabular}{|c|c|c|c|c|c|}
\hline Treatment & $\begin{array}{l}\text { Days to } \\
\text { appearance } \\
\text { of Cymes }\end{array}$ & $\begin{array}{l}\text { Days taken from } \\
\text { appearance of } \\
\text { cymes to flower } \\
\text { harvesting stage }\end{array}$ & $\begin{array}{l}\text { Duration of } \\
\text { flowering } \\
\text { flush (days) }\end{array}$ & $\begin{array}{l}\text { Total No. of } \\
\text { Flowering } \\
\text { shoots/plant }\end{array}$ & $\begin{array}{l}\text { Total No of } \\
\text { flowers/plant at } 45 \\
\text { days of interval after } \\
\text { appearance of } 1^{\text {st }} \text { cyme }\end{array}$ \\
\hline N1 P1 01 & 194.22 & 8.44 & 62.10 & 78.77 & 29.33 \\
\hline N1 P1 O2 & 195.00 & 7.55 & 54.44 & 71.44 & 19.99 \\
\hline N1 P1 O3 & 190.55 & 9.88 & 56.66 & 94.55 & 23.77 \\
\hline N1 P2 01 & 179.55 & 7.44 & 64.99 & 84.00 & 48.21 \\
\hline N1 P2 O2 & 182.33 & 7.99 & 63.88 & 70.78 & 25.99 \\
\hline N1 P2 O3 & 190.66 & 6.44 & 62.88 & 61.89 & 33.66 \\
\hline N2 P1 O1 & 177.22 & 7.99 & 72.88 & 59.77 & 34.66 \\
\hline N2 P1 O2 & 187.22 & 6.66 & 62.99 & 72.77 & 18.66 \\
\hline N2 P1 O3 & 189.66 & 7.99 & 64.88 & 74.44 & 24.33 \\
\hline N2 P2 01 & 173.55 & 7.55 & 77.55 & 85.00 & 42.66 \\
\hline N2 P2 O2 & 178.22 & 7.44 & 75.22 & 102.66 & 24.44 \\
\hline N2 P2 03 & 179.22 & 8.44 & 74.32 & 90.22 & 32.88 \\
\hline N3 P1 01 & 176.33 & 6.77 & 88.33 & 91.22 & 42.33 \\
\hline N3 P1 O2 & 175.22 & 7.55 & 75.10 & 92.22 & 28.33 \\
\hline N3 P1 O3 & 186.11 & 7.33 & 74.33 & 100.66 & 37.22 \\
\hline N3 P2 01 & 174.66 & 7.88 & 83.33 & 94.44 & 45.77 \\
\hline N3 P2 O2 & 173.77 & 9.33 & 75.77 & 81.11 & 29.77 \\
\hline N3 P2 03 & 173.96 & 6.77 & 72.88 & 92.33 & 38.77 \\
\hline $\mathrm{CD}(\mathrm{P}=0.05)$ & 8.17 & NS & NS & NS & NS \\
\hline
\end{tabular}

As reported by Bond and Alderson (1993) that substrates in equal proportion by volume e.g, soil, sand, cocopeat, Vermicompost and FYM have an important role in improving flowering parameters in Alstroemeria because of their better water holding capacity, aeration, low bulk density etc. The above results are also in conformity with the results of Bhatia et al., (2004) in which they reported that soil + FYM + Cocopeat $(2: 1: 1)$ gave maximum flower bud diameter, maximum flowers/plant and maximum flower yield. They also found minimum days to flowering (126.7) were recorded with soil + FYM + Sawdust 2:1:1. Similar results were found by Maqsood et al., (2004) where FYM + DAP application in Dahlia variabilies found highest number of flowers (44) and largest flower size $(32.97 \mathrm{~cm})$ at $40 \mathrm{~g} \mathrm{DAP} / \mathrm{m} 2+4 \mathrm{~kg}$ FYM/m2. Similarly Pathak et al., (2006) noticed a significant improvement in floral characters in Gladiolus due to bio-fertilizers and same supported by Burman et al., (2006) in Gladiolus. Also Srivastava et al., (2006) found that in tuberose application of FYM + Vermicompost resulted in early flowering increased, spike length, longest duration of flowering flush, maximum number of florets and minimum days to 50 percent flower opening. The findings in this study also lends support from findings of Dhiman and Sindhu (2007) and Gupta and Gupta (2007) who reported that growing media cocopeat + peat $(1: 1 \mathrm{v} / \mathrm{v})$ and sand + soil + FYM (1: 1: $1 \mathrm{v} / \mathrm{v})$ were found best for plant establishment shoot and flower production in Alstroemeria. 


\section{Effect of Interactions}

The data presented in table 2 and 3 showed that the interaction effect between nitrogen $\mathrm{x}$ phosphorus had a significant influence recording minimum days taken from appearance of cymes to flower harvesting stage (7.21) showing maximum duration of flowering flush 79.25 days and maximum number of flowering shoots (94.70) at N3P1. Similarly nitrogen into organic manure at $\mathrm{N} 3 \mathrm{O} 3$ recorded maximum number of flowering shoots/plant (96.49). however, the interaction between Phosphorus x Organic Manure showed significant influence on parameters recording minimum days of (7.22) from appearance of cymes to flower harvesting stage and maximum number of flowering shoots/plant (89.88). While as the interaction between nitrogen $\mathrm{x}$ phosphorus $\mathrm{x}$ organic manure had a significant influence on days to appearance of cymes recording minimum days of (173.55 days) as it has nonsignificant effect on other parameters.

Among the levels of inorganic and organic nutritional requirements, nitrogen at 250 $\mathrm{ppm} / 15$ days interval, Phosphorus at 150 $\mathrm{kg} / \mathrm{ha}$ and Vermicompost at $2.5 \mathrm{t} / \mathrm{ha}$ were found best nutritional levels for Alstroemeria cultivations, with improved flowering parameters. The treatment combination of (N3 P2 O1) produced highest benefit-cost ration and net returns.

\section{References}

Baboo, R, Ahmad, N and Singh, D 2005. Growth and flowering of African Marigold (Tagetes erecta L) affected by nitrogen and phosphorus under varying intra row spacing. Journal of Ornamental Horticulture 8(4): 312-313.

Bhatia, S, Gupta, Y.C. and Dhiman, S.R 2004. Effect of growth media and fertilizers on growth and flowering of carnation under protected conditions. Journal of Ornamental Horticulture 7(2): 174-178.

Bike, R.A. and Berg, T.J.M.V.1982. Nitrogen and potassium fertilization of the Alstroemeria cvs Orchid and Carmen grown on peat. Acta Horticulture 126:287-292.

Bloome, R, and Dambre, P. 1982. Problems in culture of Alstroemeria Verbondsnieuws Voor de Belgische Sierteelt 26(140): 643-646.

Bond, S and Alderson, P. G. 1993. Establishment and growth of the rhizome of Alstroemeria as affected by temperature and the root system. Journal of Horticulture Science 68(6): 847-853.

Burman, D, Rajnik and Upadhyaya, R.C. 2006 effect of VAM on flower production and multiplication of Gladiolus cv Candyman National Symposium on Ornamental Bulbous Crops. PP. 2-20.

Dhiman, M.R. and Sindhu, S.S. 2007. Effect of propagation media and growth regulators on bulb let formation through scale propagation in Lilium. Journal of Ornamental Horticulture 10(3): 181183.

Gupta, R and Gupta Y.C. 2007. Effect of rhizome portions and growing media on establishment of plants and shoot production in Alstroemeria (Alstroemeria Hybrids). Journal or Ornamental Horticulture 10(3): 161164.

Heins, R.D. and Wilkins, H.F. 1977. Alstroemeria cultural research 19751976, University of Minnesota. The influence of night interruption with incandescent light and shoot pruning techniques. Minnesota State Florists Bulletin, PP 1-4 
Hermans, P. 1986. Fertilizer experiments with Alstroemeria. Ziuerpflanzenbau 26(6): 228-229.

Khan, M.A. and Iftikhar, A. 2004. Growth and flowering of Gladiolus Hortalanus $\mathrm{cv}$. Wind song as influenced by various levels of NPK. International Journal of Agriculture and Biology 6(6): 10371039.

Lisiecka, A and Szczepaniak, S. 1983. Effect of NPK levels on flower yield in Alstroemeria (Alstroemeria x Hybrid Hort.). Prace Instytutu Sadownictwa I, Kwaiaciarstwa. W, Skierniewicach b Rosliny Ozdobne. J. Horticultural Abstract 8:93-99.

Lisiecka, A and Szczepaniak, S. 1992. Factors influencing the yield of Alstroemeria Acta Horticulturae 325: 379-385.

Madson, L 1995. Phosphorus fertilization of Alstroemeria. M.Sc., Thesis, Department of Plant Sciences, University of Connecticut, USA.
Maqsood, A. Khan, M.F. Hamid, A. and Hussain, A. 2004. Effect of Urea, DAP and FYM on growth and flowering of Dahlia (D. variabilies) international Journal of Agriculture and Biology 6(2): 393-395.

Pathak, G., Kumar, P. and Singh, G. 2006. Green cultivations of Gladiolus. National Symposium or Ornamental Bulbous Crops, PP.23.

Smith, M.A. Elliott, G.C. and Bridgen, M.P. 1998. Calcium and nitrogen fertilization of Alstroemeria for cut flower production. Hort. Science. The American Society for Horticultural Science 33: 55-59.

Srivastava, R. Singh, V and Chandra, R. 2006. Effect of organic manures and Azotobacter in growth, flowering and post-harvest life of tuberose (Polianthus tuberosa L) cv Double under Tarai Condions.

\section{How to cite this article:}

Samoon, S.A., Neelofar, Malik Asif and Mubashir A. Wani. 2018. Response of Flowering Parameters of Alstoemeria to Organic and Inorganic Fertilizers under Protected Conditions. Int.J.Curr.Microbiol.App.Sci. 7(09): 1528-1534. doi: https://doi.org/10.20546/ijcmas.2018.709.183 